Водянников Владимир Иванович, профессор кафедры «Частная зоотехния» ФГБОУ ВО «Волгоградский государственный аграрный университет» (400002, г. Волгоград, пр. Университетский, д. 26), доктор биологических наук, профессор, e-mail: vera.shkalenko@mail.ru

Николаев Сергей Иванович, доктор сельскохозяйственных наук, профессор, заведующий кафедрой «Кормление и разведение сельскохозяйственных животных» ФГБОУ ВО «Волгоградский государственный аграрный университет» (400002, г. Волгоград, пр. Университетский, д. 26), e-mail: nikolaevvolgau@yandex.ru

Корнилова Елена Вячеславовна, кандидат сельскохозяйственных наук, руководитель направления испытания качества кормов и продуктов животного происхождения ООО НИЦ «Черкизово» (108805, г. Москва, Троицкий АО, поселение Новофёдоровское, деревня Яковлевское, 14 Б), е-mail: e.kornilova@cherkizovo.com

\title{
THE EFFECT OF THE PROTEIN CONCENTRATE «AGRO-MATIK» ON THE DIGESTIBILITY AND USE OF NUTRIENTS BY YOUNG SHEEP
}

\author{
Y. V. Soshkin, A. K. Karapetyan, S. V. Chekhranova, \\ I. Y. Danilenko, K. S. Arstanov \\ Volgograd State Agrarian University, Volgograd, Russia
}

Received 10.09.2021

Submitted 23.11.2021

The work was carried out under a grant jointly with the Fund of Infrastructure and Educational Programs of RUSNANO Group "Nanotechnological methods of research of biogenic elements for optimizing the diets of farm animals and poultry"

\section{Summary}

The article presents and describes the results of using the Agro-Matik protein concentrate in the diets of sheep grown for meat. The use of this protein concentrate in the composition of compound feed for young sheep contributed to an increase in the coefficients of digestibility of nutrients: dry matter - by 1.7 and $1.0 \%$, crude protein - by 1.5 and $1.2 \%$, crude fat - by 1.2 and $0.8 \%$, crude fiber - by 2.1 and $1.6 \%$, nitrogen-free extractives - by 1.7 and $1.4 \%$, compared with animals of the control group. The nitrogen balance was positive in all groups, the use of nitrogen taken by the experimental sheep was higher in the experimental groups than in the control group by 1.82 and $1.50 \%$. The use of calcium and phosphorus by animals was also higher in the experimental groups, and exceeded the control indicator: for the use of calcium by $2.32-3.71 \%$, phosphorus by $3.42-4.27 \%$.

Abstract
Introduction. The existing need of the livestock industry for high-quality, high-grade products requires, instead of expensive feed means, the use of vegetable components of compound feed. Today, the Agro-Matik protein concentrate is a high-protein feed product, unique in its properties and price, free from various kinds of toxins, peroxides, pathogenic microflora, and having an extremely high digestibility in the body of farm animals. Object. The object of the study was the rams and uterus of the Volgograd breed. Materials and methods. The scientific and economic experience was carried out on sheep of the Volgograd breed in the conditions of a farm of the Sredneakhtubensky district of the Volgograd region. To conduct a scientific and economic experiment, 3 groups of newborn rams were formed on the principle of pairs of analogues, obtained by the method of industrial crossing of Volgograd ewes and Edilbaev breeds of rams-producers. The experimental rams were kept in a kennel sucked under their mothers. In the first days after birth, the newborn youngsters consumed the milk of their mothers and became accustomed to eating roughage and concentrated feed. After the rams were taught to coarse and concentrated feed, they were grazed on the pasture with their mothers. The difference between the experimental groups was that the rams of the I and II experimental groups received compound feed, in which the soybean meal was replaced with the Agro-Matik protein concentrate. At the same time, the rams of the 1st experimental group consumed the milk of their mothers, whose diet 
included the Agro-Matik protein concentrate. Results and conclusion. The introduction of AgroMatik protein concentrate into the diet of rams instead of soybean meal improved the digestibility and assimilation of nutrients in feed. Thus, the results of our studies indicate a positive effect of protein concentrate on the digestibility and use of nutrients in young sheep.

Key words: diet, ram feeding, Agro-Matik, protein concentrate, digestibility, nitrogen balance.

Citation. Soshkin Y.V., Karapetyan A.K., Chekhranova S.V., Danilenko I.Y., Arstanov K.S. The effect of the protein concentrate «Agro-Matik» on the digestibility and use of nutrients by young sheep. Proc. of the Lower Volga Agro-University Comp. 2021. 4(64). 266-275 (in Russian). DOI: 10.32786/2071-9485-2021-04-28.

Author's contribution. In this experiment, all authors took participation in the planning, implementation, and analysis of the received research results. The presented version of the article was approved by all authors.

Conflict of interests. The authors did not declare a conflict of interest.

УДК 636.3.087.7

\section{ВЛИЯНИЕ БЕЛКОВОГО КОНЦЕНТРАТА «АГРО-МАТИК» НА ПЕРЕВАРИМОСТЬ И ИСПОЛЬЗОВАНИЕ ПИТАТЕЛЬНЫХ ВЕЩЕСТВ МОЛОДНЯКОМ ОВЕЦ}

Ю. В. Сошкин, аспирант

А. К. Карапетян, доктор сельскохозяйственных наук, профессор

С. В. Чехранова, кандидат сельскохозяйственных наук, доиент

И. Ю. Даниленко, ассистент

К. С. Арстанов, аспирант

Волгоградский государственный аграрный университет, г. Волгоград

Дата поступления в редакцию 10.09.2021

Дата принятия к печати 23.11.2021

\section{Работа выполнена по гранту совместно с ФИОП РОСНАНО \\ «Нанотехнологические методы исследований биогенных элементов для оптимизации рационов сельскохозяйственных жсивотных и птицы»}

Актуальность. Существующая потребность отрасли животноводства в качественной, полноценной продукции требует, взамен дорогостоящих кормовых средств, использования растительных составляющих комбикормов. На сегодняшний день белковый концентрат «Агро-Матик» представляет собой уникальный по своим свойствам и цене высокобелковый кормовой продукт, свободный от различного рода токсинов, перекисей, патогенной микрофлоры и обладающий исключительно высокой усвояемостью в организме сельскохозяйственных животных. Объект исследования. Объектом исследования послужили баранчики и матки волгоградской породы. Материалы и методы. Научно-хозяйственный опыт был проведен на овцах волгоградской породы в условиях КФХ Кушкалов А. Б. Среднеахтубинского района Волгоградской области. Для проведения научно-хозяйственного опыта были сформированы по принципу пар-аналогов 3 группы новорожденных баранчиков, полученных методом промышленного скрещивания овцематок Волгоградской и барановпроизводителей Эдильбаевской пород. Подопытные баранчики содержались в кошаре на подсосе под матерями. В первые дни после рождения новорожденный молодняк потреблял молоко матерей и приучался к поеданию грубых и концентрированных кормов. После приучения баранчиков к грубым и концентрированным кормам их вместе с матерями выпасали на пастбище. Различие между подопытными группами заключалось в том, что баранчики I и II опытных групп получали комбикорм, в котором соевый шрот заменяли белковым концентратом «Агро-Матик». При этом баранчики I опытной группы потребляли молоко матерей, в состав рациона которых включали белковый концентрат «Агро-Матик» Результаты 
и выводы. Введение в рацион баранчиков белкового концентрата «Агро-Матик»взамен соевого шрота способствовало улучшению переваримости и усвояемости питательных веществ кормов. Таким образом, результаты проведенных нами исследований свидетельствуют о положительном влиянии белкового концентрата на переваримость и использование питательных веществ молодняком овец.

Ключевые слова: рачионы баранчиков, кормление баранчиков, «Агро-Матик», кормовые белковые конщентраты, молодняк овец.

Цитирование. Сошкин Ю. В., Карапетян А. К., Чехранова С. В., Даниленко И. Ю., Арстанов К. С. Влияние белкового концентрата «Агро-Матик» на переваримость и использование питатель-

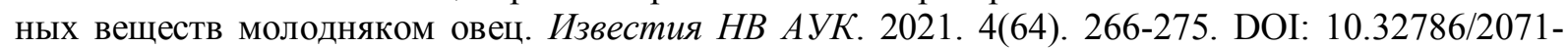
9485-2021-04-28.

Авторский вклад. В данном эксперименте все авторы принимали участие в планировании, выполнении, а также анализе полученных результатов исследований. Представленный вариант статьи одобрен всеми авторами.

Конфликт интересов. О конфликте интересов авторы не заявляли.

Введение. Увеличение объёмов производства высококачественной продукции животноводства, в том числе баранины, остается первостепенной задачей для агропромышленного комплекса РФ. Однако темпы роста производства продукции сдерживаются из-за ряда негативных факторов, основным из которых считается неполноценное кормление продуктивных животных $[3,6,8,12]$.

Сбалансировать рацион по протеину, отдельным аминокислотам и другим необходимым элементам возможно за счет совершенствования технологии заготовки кормов, их подготовки к скармливанию и глубокой переработки до выделения отдельных аминокислот и т.д. $[1,2,9]$.

При этом наиболее часто дефицит в рационах животных протеина компенсируется за счет использования кормов с высоким содержанием белка: бобовых, шротов, жмыхов, рыбной, мясокостной муки и отдельных протеин содержащих премиксов и добавок $[5,7,10,11]$.

В связи с этим изучение эффективности использования в рационах баранчиков, выращиваемых на мясо (молодая баранина) белкового концентрата «Агро-Матик», содержащего в своем составе 58 \% протеина и комплекс аминокислот, является актуальным.

Материалы и методы. Научно-хозяйственный опыт был проведен на овцах волгоградской породы в условиях КФХ Кушкалов А. Б. Среднеахтубинского района Волгоградской области.

Для проведения научно-хозяйственного опыта было сформировано по принципу пар-аналогов 3 группы новорожденных баранчиков, полученных методом промышленного скрещивания овцематок волгоградской и баранов-производителей эдильбаевской пород.

Подопытные баранчики содержались в кошаре на подсосе под матерями. В первые дни после рождения новорожденный молодняк потреблял молоко матерей и приучался к поеданию грубых и концентрированных кормов. После приучения баранчиков к грубым и концентрированным кормам их вместе с матерями выпасали на пастбище. Различие между подопытными группами заключалось в том, что баранчики I и II опытных групп получали комбикорм, в котором соевый шрот заменяли белковым концентратом «Агро-Матик». При этом баранчики I опытной группы потребляли молоко матерей, в состав рациона которых включали белковый концентрат «Агро-Матик» (рисунок 1). 
Эффективность использования белкового концентрата в кормлении овец / The effectiveness of using protein concentrate in sheep feeding

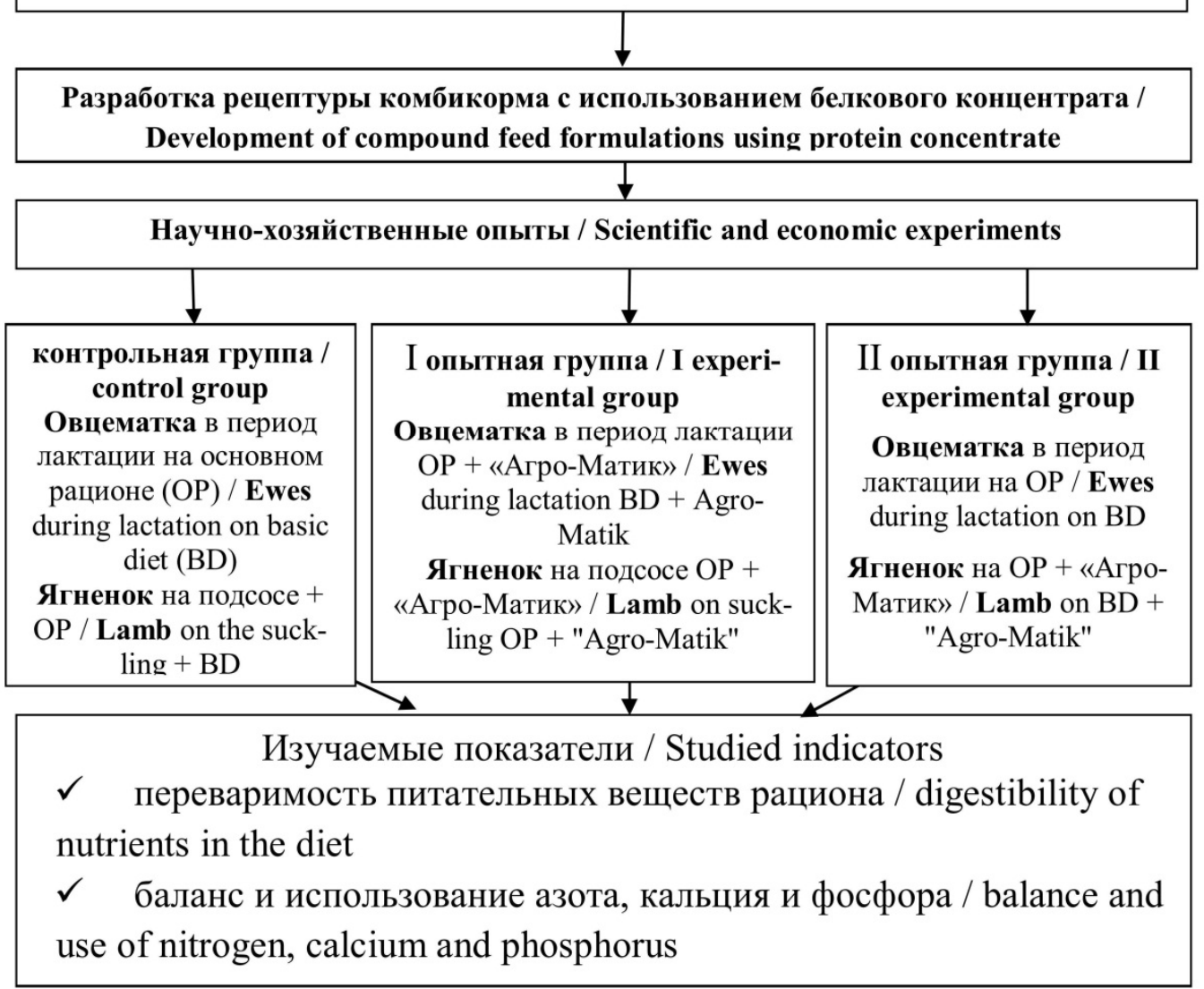

Рисунок 1 - Общая схема исследований

Figure 1 - General research scheme

Результаты и обсуждение. Рационы для подопытных баранчиков составляли по детализированным нормам с учетом возраста, живой массы и её среднесуточных приростов.

Подопытные баранчики содержались в зимний период в кошарах по группам, в весенний и летний в загонах и выпасались на естественных пастбищах. В первые дни после рождения ягнята содержались совместно с матерями и питались молоком матерей. С возрастом 7-10 дней начинали получать к поеданию сена хорошего качества и с 10-14 дней - к поеданию комбикорма.

В состав рационов подопытных баранчиков в летнее время входила трава пастбищная злаково-разнотравная, комбикорм.

Среднесуточный рацион баранчиков в опытный период состоял летом на 2 мес. жизни из травы пастбищной - 1,00 кг, комбикорма - 0,35 кг, на 3 мес. - из травы пастбищной - 2,0 кг и 0,40 кг комбикорма; на 4 мес. - из 2,5 кг пастбищной травы и 0,45 кг комбикорма (таблица 1).

Баранчики I и II опытных групп с рационом получали белковый концентрат «Агро-Матик» в составе комбикорма. При этом баранчики I опытной группы потребляли молоко матери, получавшей с рационом также белковый концентрат «Агро-Матик». Молодняк контрольной группы получал с рационом стандартный комбикорм. 
НАУКА И ВЫСШЕЕ ПРОФЕССИОНААЬНОЕ ОБРАЗОВАНИЕ

Таблица 1 - Комбикорм для молодняка овец до 4-х месячного возраста

Table 1 - Compound feed for young sheep up to 4 months of age

\begin{tabular}{|c|c|c|}
\hline Компонент, \% / Component, \% & $\begin{array}{l}\text { Для контрольной } \\
\text { группы / For the } \\
\text { control group }\end{array}$ & $\begin{array}{c}\text { Для опытной группы (I, II) / } \\
\text { For the experimental group (I, } \\
\text { II) }\end{array}$ \\
\hline Ячмень / Barley & 50 & 50 \\
\hline Овёс / Oats & 8 & 8 \\
\hline Пшеница / Wheat & 10 & 10 \\
\hline Отруби пшеничные / Wheat bran & 5 & 9 \\
\hline Шрот соевый / Soy meal & 24 & - \\
\hline «Агро-Матик» / Agro-Matik & - & 20,0 \\
\hline $\begin{array}{l}\text { Фосфат обесфторенный / Fluorinated } \\
\text { phosphate }\end{array}$ & 0,5 & 0,5 \\
\hline Мел кормовой / Chalk stern & 1 & 1 \\
\hline Соль поваренная / Table salt & 0,5 & 0,5 \\
\hline Премикс П 81-1 / Premix P 81-1 & 1 & 1 \\
\hline \multicolumn{3}{|c|}{ В рационе содержится / The diet contains: } \\
\hline ЭКЕ / Energy feed units & 1,10 & 1,10 \\
\hline $\begin{array}{l}\text { Обменная энергия, Мдж / Exchange en- } \\
\text { ergy, Mj }\end{array}$ & 11,0 & 11,0 \\
\hline Сухое вещество, г / Dry matter, g & 922 & 922 \\
\hline Сырой протеин, г / Crude protein, $g$ & 190 & 190 \\
\hline $\begin{array}{l}\text { Переваримый протеин, г / Digestible } \\
\text { protein, g }\end{array}$ & 158 & 158 \\
\hline Сырая клетчатки, г / Crude fiber, g & 64 & 64 \\
\hline Кальций, г / Calcium, g & 7,7 & 7,6 \\
\hline Фосфор, г / Phosphorus, g & 7,3 & 7,2 \\
\hline Cера, мг / Sulfur, mg & 4,7 & 4,5 \\
\hline
\end{tabular}

Питательность рационов подопытного молодняка была практически аналогичной и составляла в возрасте 2, 3, 4 месяцев: ЭКЕ- 0,96; 1,12 и 1,35, сухого вещества 695,$75 ; 961,50$ и 1181,5 г, сырого протеина - 155,2; 175,95 и 210,94 г, переваримого протеина - 126,57; 136,63 и 140,83 г.

Результаты исследования показали, что скармливание баранчикам с рационом белкового концентрата «Агро-Матик» способствовало повышению поедаемости грубых и пастбищных кормов. При этом более высокая поедаемость кормов отмечена у баранчиков I опытной группы, в состав рациона которых вводили белковый концентрат «Агро-Матик», также они потребляли молоко матери получавшей с комбикормом этот концентрат.

Различия в поедаемости кормов по группам выявлены и при проведении балансного опыта.

Известно, что переваримость питательных веществ рационов зависит от генетических и паратипических факторов, и прежде всего от породы, генотипа, возраста животных, структуры и полноценности рационов [3, 4].

Балансовый опыт проводился в специально оборудованных клетках при достижении баранчиками 4-месячного возраста. При этом баранчикам скармливалась зелёная масса трав, скошенная с используемых пастбищ.

В рационе баранчиков опытных групп содержалось 2500 г скошенной травы пастбищ и 450 г комбикорма. Отличие заключается в том, что баранчики опытных групп получали комбикорм с заменой шрота соевого белковым концентратом «Агро-Матик». 
В процессе исследований установлено, что поедаемость зелёной массы травы в контрольной группе составила 88,5 \%, что меньше, чем в I опытной группе на 8,3 \% и во II - на 5,8 \%. Концентрированные корма поедались баранчиками без остатка.

Из-за разной фактической поедаемости зелёной массы потребление питательных веществ рационов баранчиками по группам значительно варьировало. Потребление питательных веществ было более высоким у баранчиков опытных групп. Потребление сухого вещества у животных I и II опытных групп было больше, чем в контроле, на 4,56 и 2,15\%, органического вещества - на 5,74 и 3,69\%, сырого протеина - на 4,64 и 2,24 $\%$, сырого жира - на 5,74 и 3,69 \%, БЭВ - на 4,55 и 2,17\%.

В ходе исследований было установлено, что баранчики опытных групп лучше, чем их аналоги из контрольной группы, переваривали питательные вещества рационов. Отмечено, что молодняк I и II опытных групп в сравнении с контролем переваривал сухого вещества больше на 7,18 и $3,65 \%$, органического вещества - на 7,88 и 4,97 \%, сырого протеина - на 6,85 и 3,95 \%, сырого жира - на 5,94 и 2,97 \%, сырой клетчатки на 9,45 и $6,83 \%$, БЭВ - на 7,02 и 4,14\%.

Расчет коэффициентов переваримости питательных веществ показал, что у баранчиков опытных групп они были более высокими (таблица 2).

Таблица 2 - Коэффициенты переваримости питательных веществ рационов, \%

Table 2 - Coefficients of digestibility of nutrients in rations, $\%$

\begin{tabular}{|l|c|c|c|}
\hline \multirow{2}{*}{\multicolumn{1}{|c|}{ Показатель / Indicator }} & \multicolumn{3}{|c|}{ Группа / Group } \\
\cline { 2 - 4 } & $\begin{array}{c}\text { Контрольная / } \\
\text { Control }\end{array}$ & $\begin{array}{c}\text { I опытная / I ex- } \\
\text { perimental }\end{array}$ & $\begin{array}{c}\text { II опытная / II ex- } \\
\text { perimental }\end{array}$ \\
\hline Сухое вещество / Dry matter & $68,1 \pm 0,32$ & $69,8 \pm 0,37$ & $69,1 \pm 0,28$ \\
\hline $\begin{array}{l}\text { Органическое вещество / Organic } \\
\text { matter }\end{array}$ & $69,3 \pm 0,40$ & $71,5 \pm 0,38$ & $71,2 \pm 0,42$ \\
\hline Сырой протеин / Crude protein & $72,3 \pm 0,54$ & $73,8 \pm 0,41$ & $73,5 \pm 0,52$ \\
\hline Сырой жир / Crude fat & $67,7 \pm 0,38$ & $68,9 \pm 0,47$ & $68,5 \pm 0,44$ \\
\hline Сырая клетчатка / Crude fiber & $54,2 \pm 0,31$ & $56,3 \pm 0,35$ & $55,8 \pm 0,41$ \\
\hline $\begin{array}{l}\text { БЭВ / Nitrogen-free extractive } \\
\text { substances }\end{array}$ & $72,4 \pm 0,43$ & $74,1 \pm 0,51$ & $73,8 \pm 0,37$ \\
\hline
\end{tabular}

Здесь и далее: *P $\geq 0,95 ; * * \mathrm{P} \geq 0,99 ; * * * \mathrm{P} \geq 0,999$

Так, животные опытных групп превосходили аналогов контрольной группы по коэффициенту переваримости сухого вещества соответственно на $1,7(\mathrm{P}>0,99)$ и 1,0 \% $(\mathrm{P}>$ $0,95)$, органического вещества - на $2,2(\mathrm{P}>0,99)$ и $1,9 \%(\mathrm{P}>0,95)$, сырого протеина - на $1,5(\mathrm{P}>0,95)$ и $1,2 \%(\mathrm{P}>0,95)$, сырого жира - на $1,2 \%(\mathrm{P}>0,95)$ и $0,8 \%$, сырой клетчатки - на 2,1 $(\mathrm{P}>0,99)$ и 1,6 \% $(\mathrm{P}>0,95)$, БЭВ - на 1,7\% $(\mathrm{P}>0,95)$ и $1,4 \%(\mathrm{P}>0,95)$.

Следовательно, введение в рацион подопытного молодняка белкового концентрата «Агро-Матик» способствовало повышению потребления и переваримости питательных веществ рационов.

Из числа опытных групп более высокие коэффициенты переваримости питательных веществ были у животных I опытной группы, потреблявших белковый концентрат «Агро-Матик» и молоко матерей, получавших с рационом данный концентрат. животных.

Далее были изучены показатели белкового обмена в организме подопытных

Исследованиями установлено, что больше азота приняли животные опытных групп. Баранчики I и II опытных групп азота потребляли больше в сравнении с аналогами из контрольной группы, соответственно на 4,65 и 2,26 \%. Животные опытных групп больше переваривали азот. Так, в сравнении с аналогами из контрольной группы они лучше переваривали азот соответственно на 6,84 и $3,93 \%$. 


\section{***** I3BECTYЯ ***** \\ НИЖНЕВОАЖСКОГО АГРОУНИВЕРСИТЕТСКОГО КОМПАЕКСА: \\ НАУКА И ВЫСШЕЕ ПРОФЕССИОНААЬНОЕ ОБРАЗОВАНИЕ}

При этом баланс азота в организме подопытных баранчиков во всех группах был положительным. Наибольшее количество азота было отложено в организме баранчиков опытных групп. Так, в организме баранчиков I опытной группы было отложено азота больше в сравнении с аналогами из контрольной группы 14,52 и 10,23 \%. У баранчиков I и II опытных групп усвояемость азота была выше в сравнении с контролем от принятого на 1,82 и $1,50 \%$, от переваренного - на 2,53 и 1,62 \% (таблица 3 ).

Таблица 3 - Среднесуточный баланс азота, г

Table 3 - Average daily nitrogen balance, $g$

\begin{tabular}{|l|c|c|c|}
\hline \multirow{2}{*}{ Показатель / Indicator } & \multicolumn{3}{|c|}{ Группа / Group } \\
\cline { 2 - 4 } & $\begin{array}{c}\text { Контрольная / } \\
\text { Control }\end{array}$ & $\begin{array}{c}\text { I опытная / } \\
\text { I experimental }\end{array}$ & $\begin{array}{c}\text { II опытная / } \\
\text { II experimental }\end{array}$ \\
\hline Принято с кормом / Accepted with feed & 31,34 & 32,80 & 32,05 \\
\hline Переварено / Digested & 22,66 & 24,21 & 23,55 \\
\hline Выделено / Excreted: & 8,68 & 8,59 & 8,50 \\
\hline с калом / with feces & 16,60 & 17,24 & 16,87 \\
\hline с мочой / with urine & 25,28 & 25,86 & 25,37 \\
\hline Всего / Tоtal & 6,06 & 6,94 & 6,68 \\
\hline Отложено в теле / Deposited in the body & 19,34 & 21,16 & 20,84 \\
\hline $\begin{array}{l}\text { Усвоено, \% / Assimilated, \%: } \\
\text { от принятого / from accepted }\end{array}$ & 26,14 & 28,67 & 28,36 \\
\hline от переваренного / from digested
\end{tabular}

Таким образом, введение в рацион баранчиков, выращиваемых на мясо, белкового концентрата «Агро-Матик» оказало положительное влияние на баланс азота. Наиболее высокий коэффициент использования азота установлен у баранчиков I опытной группы, потреблявших белковый концентрат «Агро-Матик» и молоко матерей, в составе рациона которых также имелся изучаемый концентрат.

В ходе исследований нами был изучен минеральный обмен в организме подопытного молодняка (таблицы 4, 5).

В результате проведения балансового опыта было установлено, что баранчики опытных групп потребляли в сравнении с аналогами из контроля кальция больше соответственно на 3,85 (P > 0,95) и 1,93 \%. В организме молодняка I и II опытных групп было отложено кальция больше, чем аналогами из контрольной группы соответственно на $13,19(\mathrm{P}>0,99)$ и 7,66 \% (таблица 4).

Таблица 4 - Среднесуточный баланс кальция, г

Table 4 - Average daily calcium balance, $g$

\begin{tabular}{|l|c|c|c|}
\hline \multirow{2}{*}{\multicolumn{1}{|c|}{ Показатель / Indicator }} & \multicolumn{3}{|c|}{ Группа / Group } \\
\cline { 2 - 4 } & $\begin{array}{c}\text { Контрольная / } \\
\text { Control }\end{array}$ & $\begin{array}{c}\text { I опытная / } \\
\text { I experimental }\end{array}$ & $\begin{array}{c}\text { II опытная / } \\
\text { II experimental }\end{array}$ \\
\hline Принято с кормом / Accepted with feed & $5,71 \pm 0,07$ & $5,93 \pm 0,05$ & $5,82 \pm 0,08$ \\
\hline Выведено с калом / Excreted with feces & $2,28 \pm 0,05$ & $2,21 \pm 0,06$ & $2,28 \pm 0,04$ \\
\hline Выведено с мочой / Excreted with urine & $1,08 \pm 0,03$ & $1,06 \pm 0,05$ & $1,01 \pm 0,03$ \\
\hline Выведено всего / Total excreted & $3,36 \pm 0,06$ & $3,27 \pm 0,04$ & $3,29 \pm 0,05$ \\
\hline Отложено в теле / Deposited in the body & $2,35 \pm 0,04$ & $2,66 \pm 0,03$ & $2,53 \pm 0,04$ \\
\hline $\begin{array}{l}\text { Усвоено от принятого, \% / Digested from ac- } \\
\text { серted }\end{array}$ & $41,15 \pm 0,28$ & $44,86 \pm 0,32$ & $43,47 \pm 0,21$ \\
\hline
\end{tabular}

При этом было выведено из организма кальция с калом и мочой больше у баранчиков контрольной группы соответственно на 2,75 и $2,13 \%$, в связи с чем усвояемость кальция от принятого в организме молодняка I и II опытных групп была выше, чем у аналогов из контроля на $3,71(\mathrm{P}>0,999)$ и $2,32 \%(\mathrm{P}>0,99)$. 
Характер обмена фосфора в организме подопытного молодняка был аналогичным. Фосфора было потреблено баранчиками I и II опытных групп больше в сравнении с аналогами, не потреблявшими белковый концентрат «Агро-Матик» на 3,41 и 0,53 \%.

Из организма баранчиков контрольной группы выделено с калом и мочой фосфора больше, чем у аналогов опытной группы, на 3,05 и 4,65 \%. У баранчиков, потреблявших с рационом белковый концентрат «Агро-Матик», отложено в организме фосфора больше, чем у аналогов из контроля, соответственно на 18,9 (P > 0,99) и 12,6 \% (P > 0,95). Усвояемость фосфора в организме молодняка опытных групп была выше соответственно на 4,27 (P > 0,999) и 3,42 (P > 0,999).

Таблица 5 - Среднесуточный баланс фосфора, г

Table 5 - Average daily phosphorus balance, $\mathrm{g}$

\begin{tabular}{|l|c|c|c|}
\hline \multicolumn{1}{|c|}{ Показатель / Indicator } & \multicolumn{3}{|c|}{ Группа / Group } \\
\cline { 2 - 4 } & $\begin{array}{c}\text { Контрольная / } \\
\text { Control }\end{array}$ & $\begin{array}{c}\text { I опытная / } \\
\text { I experimental }\end{array}$ & $\begin{array}{c}\text { II опытная / } \\
\text { II experimental }\end{array}$ \\
\hline Принято с кормом / Accepted with feed & $3,81 \pm 0,04$ & $3,94 \pm 0,06$ & $3,83 \pm 0,04$ \\
\hline Выведено с калом / Excreted with feces & $1,67 \pm 0,03$ & $1,52 \pm 0,5$ & $1,52 \pm 0,03$ \\
\hline Выведено с мочой / Excreted with urine & $1,03 \pm 0,04$ & $1,10 \pm 0,03$ & $1,06 \pm 0,05$ \\
\hline Выведено всего / Total excreted & $2,70 \pm 0,05$ & $2,62 \pm 0,07$ & $2,58 \pm 0,04$ \\
\hline Отложено в теле / Deposited in the body & $1,11 \pm 0,04$ & $1,32 \pm 0,03$ & $1,25 \pm 0,02$ \\
\hline Усвоено от принятого, \% / Digested from accepted & $29,18 \pm 0,32$ & $33,45 \pm 0,41$ & $32,60 \pm 0,35$ \\
\hline
\end{tabular}

Таким образом, введение в рацион баранчикам белкового концентрата «АгроМатик» способствовало активизации в их организме обмена кальция и фосфора.

Выводы. Введение в рацион баранчиков белкового концентрата «Агро-Матик» взамен соевого шрота способствовало улучшению переваримости и усвояемости питательных веществ кормов. Коэффициент переваримости сухого вещества у баранчиков опытных групп в сравнении с аналогами из контроля был выше, соответственно на 1,7 и $1,0 \%$, сырого протеина - на 1,5 и $1,2 \%$, сырого жира - на 1,2 и $0,8 \%$, сырой клетчатки - на 2,1 и 1,6\%, БЭВ - на 1,7 и 1,4\%.

Использование кальция и фосфора животными было также выше в опытных группах и превзошло показатель контроля: по использованию кальция на 2,32-3,71%, фосфора - на 3,42-4,27 \%.

Таким образом, результаты проведенных нами исследований свидетельствуют о положительном влиянии белкового концентрата на переваримость и использование питательных веществ молодняком овец.

\section{Библиографический список}

1. Андрушко А. М., Завгородняя Г. В., Дмитрик И. И. Оценка товарных свойств овчин баранчиков породы джалгинский меринос при разных технологиях выращивания // Главный зоотехник. 2020. № 1. С. 48-54.

2. Интенсивность роста ягнят в подсосный период при разной молочности овцематок / Н. Г. Чамурлиев [и др.] // Овцы, козы, шерстяное дело. 2019. № 4. С. 25-26.

3. Переваримость питательных веществ рациона молочными козами при разном уровне протеина / С. И. Новопашина [и др.] // Овцы, козы, шерстяное дело. 2012. № 2. С. 64.

4. Проблемы и перспективы развития овцеводства на юге России / В. И. Комлацкий [и др.] // Зоотехния. 2019. № 2. С. 6-12.

5. Салаев Б. К. Переваримость и использование питательных веществ рационов калмыцкими курдючными суягными овцематками // Нива Поволжья. 2016. № 2 (39). С. 45-51.

6. Селезнев И. П. Влияние сбалансированного кормления на мясные качества молодняка овец // Синергия Наук. 2018. № 29. С. 1619-1625. 
7. Совершенствование выращивания молодняка овец романовской породы / А. А. Механиков [и др.] // Молочно-хозяйственный вестник. 2018. № 3 (31). С. 54-61.

8. Физиологические показатели и резистентность организма баранчиков при скармливании гранулированных экструдированных комбикормов-концентратов / Н. Г. Чамурлиев [и др.] // Известия Нижневолжского агроуниверситетского комплекса: наука и высшее профессиональное образование. 2018. № 3 (51). С. 247-251.

9. Comparison of three feeding regimens on blood fatty acids metabolites of wujumqin sheep in inner Mongolia / Y. Jin [et al.] // Animals. 2021. V. 11. № 4. P. 1080.

10. Evaluating the effects of finishing diet and feeding location on sheep performance, carcass characteristics, and internal parasites / D. L. Ragen [et al.] // Journal of Animal Science and Technology. 2021. V. 63. № 3. P. 545.

11. Feeding selection of sheep and alpaca on puna tussock rangelands grazed previously by cattle / C. Quispe [et al.] //Small Ruminant Research. 2021. V. 197. P. 106349.

12. The effects of vehicle type, transport duration and pre-transport feeding on the welfare of sheep transported in low temperatures / F. Carnovale [et al.] // Animals. 2021. V. 11. № 6. P. 1659.

Conclusions. The introduction of Agro-Matik protein concentrate into the diet of sheep instead of soy meal helped to improve the digestibility of feed nutrients. The coefficient of digestibility of dry matter in the rams of the experimental groups in comparison with the analogues from the control was higher, respectively, by 1.7 and $1.0 \%$, crude protein - by 1.5 and $1.2 \%$, crude fat - by 1.2 and $0.8 \%$, crude fiber - by 2.1 and $1.6 \%$, nitrogen-free extractives - by 1.7 and $1.4 \%$.

The use of calcium and phosphorus by animals was also higher in the experimental groups, and exceeded the control indicator: for the use of calcium by $2.32-3.71 \%$, phosphorus by $3.42-4.27 \%$.

Thus, the results of our studies indicate a positive effect of protein concentrate on the digestibility and use of nutrients by young sheep.

\section{References}

1. Andrushko A. M., Zavgorodnyaya G. V., Dmitrik I. I. Ocenka tovarnyh svojstv ovchin baranchikov porody dzhalginskij merinos pri raznyh tehnologiyah vyraschivaniya // Glavnyj zootehnik. 2020. № 1. P. 48-54.

2. Intensivnost' rosta yagnyat $\mathrm{v}$ podsosnyj period pri raznoj molochnosti ov-cematok / N. G. Chamurliev [i dr.] // Ovcy, kozy, sherstyanoe delo. 2019. № 4. P. 25-26.

3. Perevarimost' pitatel'nyh veschestv raciona molochnymi kozami pri raznom urovne proteina / S. I. Novopashina [i dr.] // Ovcy, kozy, sherstyanoe delo. 2012. № 2. P. 64.

4. Problemy i perspektivy razvitiya ovcevodstva na yuge Rossii / V. I. Komlackij [i dr.] // Zootehniya. 2019. № 2. P. 6-12.

5. Salaev B. K. Perevarimost' i ispol'zovanie pitatel'nyh veschestv racionov kalmyckimi kurdyuchnymi suyagnymi ovcematkami // Niva Povolzh'ya. 2016. № 2 (39). P. 45-51.

6. Seleznev I. P. Vliyanie sbalansirovannogo kormleniya na myasnye kachestva molodnyaka ovec // Sinergiya Nauk. 2018. № 29. P. 1619-1625.

7. Sovershenstvovanie vyraschivaniya molodnyaka ovec romanovskoj porody / A. A. Mehanikov [i dr.] // Molochno-hozyajstvennyj vestnik. 2018. № 3 (31). P. 54-61.

8. Fiziologicheskie pokazateli i rezistentnost' organizma baranchikov pri skarmlivanii granulirovannyh jekstrudirovannyh kombikormov-koncentratov / N. G. Chamurliev [i dr.] // Izvestiya Nizhnevolzhskogo agrouniversitetskogo kompleksa: nauka i vysshee professional'noe obrazovanie. 2018. № 3 (51). P. 247-251.

9. Comparison of three feeding regimens on blood fatty acids metabolites of wujumqin sheep in inner Mongolia / Y. Jin [et al.] // Animals. 2021. V. 11. № 4. P. 1080.

10. Evaluating the effects of finishing diet and feeding location on sheep performance, carcass characteristics, and internal parasites / D. L. Ragen [et al.] // Journal of Animal Science and Technology. 2021. V. 63. № 3. P. 545. 


\title{
***** Y3BECTYЯ ***** \\ НИЖНЕВОАЖСКОГО АГРОУНИВЕРСИТЕТСКОГО КОМПАЕКСА: НАУКА И ВЫСШЕЕ ПРОФЕССИОНААЬНОЕ ОБРАЗОВАНИЕ
}

11. Feeding selection of sheep and alpaca on puna tussock rangelands grazed previously by cattle / C. Quispe [et al.] //Small Ruminant Research. 2021. V. 197. P. 106349.

12. The effects of vehicle type, transport duration and pre-transport feeding on the welfare of sheep transported in low temperatures / F. Carnovale [et al.] // Animals. 2021. V. 11. № 6. P. 1659.

\section{Author's Information}

Soshkin Yuri Vladimirovich, postgraduate student of the Volgograd State Agrarian University (26 University Avenue, Volgograd, 400002), e-mail: yurvlad77@list.ru

Karapetyan Angela Keropovna, professor of the department "Feeding and breeding of farm animals" of the Volgograd State Agrarian University (26 University Avenue, Volgograd, 400002), Doctor of Agricultural Sciences, e-mail: akkarapetyan@bk.ru

Chekhranova Svetlana Viktorovna, Associate Professor of the Department "Feeding and Breeding of Farm Animals" of the Volgograd State Agrarian University (26 University Avenue, Volgograd, 400002), Candidate of Agricultural Sciences, e-mail: schekhranova@mail.ru

Danilenko Irina Yurievna, Assistant of the Department "Feeding and Breeding of Farm Animals" of the Volgograd State Agrarian University (26 University Avenue, Volgograd, 400002), e-mail: taranova_15@mail.ru Arstanov Kairat Samatovich, postgraduate student of the Volgograd State Agrarian University (26 University Avenue, Volgograd, 400002), e-mail: kafedra-kormlenie@volgau.com

Информация об авторах

Сошкин Юрий Владимирович, аспирант ФГБОУ ВО «Волгоградский государственный аграрный университет» (400002, г. Волгоград, пр. Университетский, д. 26), e-mail: yurvlad77@)list.ru

Карапетян Анжела Кероповна, профессор кафедры «Кормление и разведение сельскохозяйственных животных» ФГБОУ ВО «Волгоградский государственный аграрный университет» (400002, г. Волгоград, пр. Университетский, д. 26), доктор сельскохозяйственных наук, e-mail: a.k.karapetyan @,bk.ru

Чехранова Светлана Викторовна, доцент кафедры «Кормление и разведение сельскохозяйственных животных» ФГБОУ ВО «Волгоградский государственный аграрный университет» (400002, г. Волгоград, пр. Университетский, д. 26), кандидат сельскохозяйственных наук, e-mail: schekhranova@mail.ru

Даниленко Ирина Юрьевна, ассистент кафедры «Кормление и разведение сельскохозяйственных животных» ФГБОУ ВО «Волгоградский государственный аграрный университет» (400002, г. Волгоград, пр. Университетский, д. 26), e-mail: taranova_15@mail.ru

Арстанов Кайрат Саматович, аспирант ФГБОУ ВО «Волгоградский государственный аграрный университет» (400002, г. Волгоград, пр. Университетский, д. 26), e-mail: kafedrakormlenie@volgau.com

DOI: 10.32786/2071-9485-2021-04-29

\section{OPTIMIZATION OF NUTRITIONAL VALUE OF EXTRUDED FEED FOR TROUT USING CRYSTALLINE AMINO ACIDS}

\author{
A. E. Yapontsev, S. V. Chekhranova, Y. M. Batrakova, O. V. Samofalova, A. E. Stavtsev \\ Volgograd State Agrarian University, Volgograd
}

Received 22.09.2021

Submitted 25.11.2021

The work was carried out under a grant from the Fund of Infrastructure and Educational Programs of RUSNANO Group with the Astrakhan State Technical University "Application of artificial feeds based on low molecular weight biologically effective essential nanoadditives for aquaculture facilities"

Summary

Experimental data on the use of crystalline amino acid supplements in trout feed in order to reduce the level of crude protein and feed cost are presented.

\section{Abstract}

Introduction. There is now credible evidence to support a significant reduction in fishmeal use in fish and shrimp diets using a range of plant protein sources, provided the diets are properly supplemented with essential amino acids. The limit of the possible reduction in the cost of marine resources is clearly supported by the possibility of reducing fishmeal levels by up to $5 \%$ in diets for Atlantic salmon. In 